Federal Reserve Bank of Minneapolis

Research Department Staff Report 242

December 1997

\title{
Needed: A Theory of Total Factor Productivity*
}

\author{
Edward C. Prescott \\ Federal Reserve Bank of Minneapolis \\ and University of Minnesota
}

\begin{abstract}
This paper evaluates the argument that differences in physical and intangible capital can account for the large international income differences that characterize the world economy today. The finding is that they cannot. Savings rate differences are of minor importance. What is all-important is total factor productivity. In addition, the paper presents industry evidence that total factor productivities differ across countries and time for reasons other than differences in the publicly available stock of technical knowledge. These findings lead me to conclude a theory of TFP is needed. This theory must account for differences in TFP that arise for reasons other than growth in the stock of technical knowledge.
\end{abstract}

*The views expressed herein are those of the author and not necessarily those of the Federal Reserve Bank of Minneapolis or the Federal Reserve System. 


\section{Introduction}

The typical worker in a rich country such as Switzerland or the United States is 20 or 30 times more productive and, therefore, richer than the typical worker in a poor country such as Haiti or Nigeria. These between-country differences in worker productivities are a number of times bigger than differences in worker productivities within a country. Why are there such large differences in productivities and, therefore, incomes across countries?

One factor determining international income differences is differences in endowments of natural resources. Some countries are rich because they have a large per capita endowment of oil, but such countries are small in number and do not have large populations. A much more important determinant of international income differences is differences in capital per worker. Capital per worker is greater in rich countries and is an important reason why workers in rich countries are more productive than their counterparts in poor countries. However, capital per worker is not the story.

The story is the large differences in output per worker that cannot be accounted for by differences in capital per worker; that is, differences in total factor productivity. The reason that capital per worker is high in rich countries is that total factor productivities are high in rich countries. Differences in savings rates also affect capital stocks, but these effects are small. Total factor productivity determines labor productivity not only directly but also indirectly by determining capital per worker.

In this paper, I explore whether these conclusions hold if the concept of accumulable capital is broadened to include intangible as well as tangible capital. I conclude that they do hold. This finding leads me to the conclusion that understanding international income differences requires a theory of total factor productivity. 
One factor contributing to the growth of total factor productivity is increases in what Kuznets (1966) calls useable knowledge. This factor explains why total factor productivity in the United States is four times greater today than it was in 1850 . This factor does not explain why total factor productivity in the United States is about four times greater today than it is in India. Make no mistake, knowledge used in the United States is there to be used by the Indians to increase their total factor productivity. The reason that Indian workers are less productive after correcting for stocks of tangible and intangible capital is that this useable knowledge is not as fully exploited there as it is in the United States. A successful theory of international income differences must explain why this is the case.

I am not arguing that technologies developed elsewhere in the world can be adopted without some further country-specific research and development. In agriculture, for example, research is needed to adapt a frontier technology to specific local requirements. Improved crop varieties need to be developed for each agro-ecological zone with appropriate consideration for local soils, climate, day length, diseases, and pests. But the frontier research does not need to take place in each country. As the green revolution in rice and wheat has shown, improved varieties can be developed in international research programs with only modest adaptive research taking place at the local level. I am arguing that advances in the stock of useable knowledge have reduced significantly the costs of developing improved seeds for a given agro-ecological zone.

Until recently, all major civilizations have had roughly the same standard of living. There was output growth, but populations increased so as to keep standards of living constant. Sustained increase in per capita output, which Kuznets (1966) calls modern economic growth, is a recent phenomenon. Economic historians typically date modern economic growth as beginning in England about 1780 and slightly later in the United States and continental Europe. A success- 
ful theory of total factor productivity must explain why total factor productivity began to grow after being constant for over five millenniums.

The reason current income differences are huge is that sustained growth in total factor productivity and the resulting growth in per capita income began at different dates in different countries and proceeded at different rates. The reason residents of Western Europe and the countries they settled were, on average, 12 times richer than residents of China in 1950 is that sustained growth in total factor productivity began about 1800 in the West, well over 100 years before it began in China. In the years around 1800, the West was only slightly richer than China. ${ }^{1}$ After 1800 , total factor productivity grew steadily in the West, while it remained more or less constant in China up to 1950. This is what led to the large differences in per capita income between the West and China in 1950. A successful theory of total factor productivity must explain why China's total factor productivity did not begin its sustained growth until well into the twentieth century.

Some of the current huge international income differences are a consequence of what happened to total factor productivity subsequent to the beginning of modern economic growth. The Philippines and South Korea provide a dramatic example. In 1960, both these countries had already entered into modern economic growth and had similar productivity and income levels. In 1995, however, the South Koreans were, on average, four times richer than the Filipinos. The reason is that in the 1960-95 period, South Korea experienced what is by historical standards incredibly rapid growth, while the Philippines grew slightly slower than the world average. A successful theory must explain why a growth miracle occurred in South Korea but not in the Philippines. 
In Section 2, I review what I see as the important facts concerning per capita income differences across countries and time, that is, the panel behavior of countries' per capita incomes. I examine the degree of disparity now and in the past and compare the development experiences of the East and the West since 1820. Finally, I report on the development experiences of countries after reaching a critical level. I find that the later a country reached this level, the fewer years it took to reach twice that level.

Section 3 evaluates neoclassical growth theory as a theory of international income differences. This theory assumes a production technology with constant returns to scale. At a point in time, this technology is common across countries and typically is characterized by a single aggregate production function. With this theory, differences in savings rates give rise to differences in steady-state relative levels of income. In a seminal paper, Solow (1957) recognizes that his model is not a theory of international income differences because differences in savings rates can account for only a small part of international income differences. After Solow wrote this paper, however, the concept of capital has been broadened to include intangible capital, in particular, human capital. This increases the importance of capital in production, and the greater the importance of capital, the larger the difference in steady-state incomes associated with any given difference in savings rates. The conclusion of my analysis is that growth theory still fails as a theory of international income differences, even if the concept of capital is broadened to include human and other forms of intangible capital. It fails because differences in savings rates cannot account for the great disparity in per capita incomes unless investment in intangible capital is implausibly large.

Section 4 considers a model economy with a human capital production sector as well as a goods and services production sector. Only if diminishing returns to individuals investing in their 
human capital are small can differences in time allocated to enhancing human capital give rise to large differences in steady-state per capita products and incomes. But if this is the case, the implied time allocated to enhancing human capital is implausibly large. This leads me to the conclusion that adding a training sector to the neoclassical growth model does not make that model a theory of international income differences. This and the previous finding lead me to conclude that there must be a factor or factors other than the accumulation of capital that accounts for differences in worker productivities across countries.

Section 5 presents evidence that the total factor productivities of industries differ across countries at a point in time. The large rich countries have surprisingly large differences in productivities across manufacturing industries. In steel manufacturing, Japan is 40 percent more productive than the United States, while in food manufacturing, Japan is only one-third as productive. I also review in Section 5 a study by Clark (1987), who finds huge cross-country differences in productivities in the textile industries in 1910. In New England and Canada, workers were seven times as productive as workers in India, even though the machines and the skills of the workers were the same. Clark makes a convincing case that differences in work practices are the reason for the large differences in total factor productivity. Why were work practices different?

Further evidence that total factor productivity is affected by factors other than the stock of knowledge is provided by two studies: one in the textile industry and the other in coal mining. In both cases, the time pattern of productivity is related to the ability and incentives of factor suppliers to resist the efficient use of an existing technology. The first study is that of Wolcott (1994). She compares the Indian and Japanese textile industries in the 1920-38 period. She finds that total factor productivity grew much more slowly in India than it did in Japan. Her explana- 
tion is that Indian workers had the ability and incentive to resist the adoption of more productive work practices. The second case study is the postwar subsurface coal mining industry in the United States. During one decade-long period, labor productivity declined by a factor of two. During another decade-long period, labor productivity almost tripled. What seems crucial in explaining these productivity movements are movements in the price of oil, a substitute for coal, and not changes in the stock of knowledge. When oil prices are low, there are no incentives to resist the use of more efficient work practices, and productivity is high. I conclude that factors besides the stock of technological knowledge determine relative total factor productivity levels at a point in time.

\section{Some Development Facts}

Through all but the most recent recorded history, a more or less common standard of living characterized all major civilizations. This standard of living was significantly above the subsistence level. In 1688, the poorest quarter of the population in England, the paupers and the cottagers, survived on a consumption level of only one-fourth the national average. ${ }^{2}$ Famines did occasionally occur. However, famine was not endemic and almost always was the result of pestilence or war.

The Malthusian model accounts well for this relative constancy of living standards prior to 1800 . By this I mean that all civilizations controlled their population at a level that maintained the average standard of living at roughly a common level. Before 1800, there were some technological advances that resulted in increases in total factor productivity. However, these improvements in technology did not lead to sustained increases in living standards. The gains were dissipated by a rising population facing limited natural resources. This is just what the Malthusian model predicts. 
Today, in contrast, huge differences in living standards exist across countries. The richest countries are about 30 times richer than the poorest ones when incomes are measured with the Summers and Heston (1991) purchasing power parity prices. These income differences began to emerge in the first half of the nineteenth century and increased steadily until the middle of the twentieth century. The reason for this increase in living standards is that some countries, namely, the Western European countries and their offshoots, began sustained, rapid growth 150 or more years earlier than others.

Maddison (1991) and Mokyr (1990) argue that per capita incomes in Western Europe had actually begun to grow about 1500, but at a slow rate. Maddison (1991) estimates that per capita income in Western Europe roughly doubled in the 300 -year period from 1500 to 1800 , which is a century growth rate of 25 percent. In comparison, the century growth rate in per capita product or income after 1800 for these early developers is close to 500 percent, about 20 times larger than in the previous 300 years. This is a dramatic change, and there is no evidence that this rapid growth will not continue.

The experience of Western Europe in the 1450-1750 period has some remarkable parallels to that of China in the 950-1250 period. ${ }^{3}$ Populations and living standards roughly doubled, and the rate of innovation increased. Iron production per capita grew by comparable amounts, while the price of iron relative to grain fell by a factor of four. Commerce and trade increased. Subsequent to these periods of sustained, but slow by modern standards, growth, the experiences of China and Western Europe diverged. In China, living standards returned to their 950 level and remained there for centuries, while in Europe, growth accelerated, with living standards doubling every 35 or 40 years. Why didn't modern economic growth start in China in the late fourteenth century after the Mongolian invaders were expelled? 
Tables 1 and 2 report estimates for the per capita income in the East and the West for selected years since 1820. Per capita output in both tables represents the average for the region rather than the average for the countries in the region. This is to say that per capita output of each region reported in the tables is the sum of the output of the countries that comprise the region divided by the sum of these countries' populations. Together, these sets of countries constitute over three-fourths of the world's population.

The East consists of all those Eastern countries with current populations exceeding 100 million, namely, China, Pakistan, India, Bangladesh, Indonesia, and Japan, as well as Burma, the Philippines, South Korea, Taiwan, and Thailand. Data unavailability precluded the inclusion of the other Eastern countries. The West consists of the Western European countries and their offshoots. A country is an offshoot of the West if its ethnic stock is primarily Western European. Countries meeting this criterion are Canada, Mexico, and the United States in North America; Argentina, Brazil, and Chile in South America; and Australia and New Zealand. African countries, Eastern European countries that were part of the Ottoman Empire, Iran, Latin American countries with ethnic stocks that are not primarily of Western European descent, and countries that were part of the former Soviet Union are in neither category.

What Table 1 and Table 2 show is that differences in living standards increased for 150 years as living standards in the West grew rapidly, while living standards stagnated or grew slowly in the East with the notable exception of Japan. The situation changed in the last half of the twentieth century. Living standards continued to grow rapidly in the West. In the East, however, they began to grow at an even more rapid rate. A consequence of this is that after increasing for roughly 150 years, the income gap between the East and the West decreased dramatically over the last 40 years. If current trends continue, it will not be long before living standards in the 
East catch up with living standards in the West. Why did modern economic growth start in the West, and what change in the East produced its extremely rapid growth in the last half of the twentieth century? These are important questions that a theory of development must answer.

Some of the decrease in the differences in living standards is attributed to the improved performance of India and China, where more than two-thirds of the East's population resides. Some of the decrease is attributed to the dramatic growth experiences of Japan, South Korea, Singapore, and Taiwan over the postwar period. Individually, no country in the West has achieved the rapid growth rates of these countries over any periods of equivalent length. In the 25-year 1955-80 period, Japan increased its per capita output by a factor of five as did Taiwan in the 1965-90 period. South Korea had an even more remarkable development experience in the 1965-90 period, increasing its per capita product 6.3 times. What changed in these countries that caused these growth miracles?

These Eastern countries, which entered modern economic growth much later than their Western counterparts, were able to grow faster once they achieved the modest level of 10 percent of the 1985 U.S. level than Western countries that achieved this level earlier. South Korea and Japan required less than 10 years to double living standards once they reached this level. The United States, in contrast, took 44 years to achieve this feat, starting in 1856. This pattern tends to hold for later developers in the world outside the East. In general, countries that entered into modern economic growth later have been able to double their per capita income levels in a much shorter time than countries that entered earlier. Figure 1 plots the number of years a country took to go from 10 to 20 percent of the 1985 U.S. per capita output level versus the first year that country achieved the 10 percent level. 
The set of countries on which the figure is based includes those countries in which the 1970 population exceeds 1 million and in which the 1965 per capita output level exceeds 10 percent of the 1985 U.S. per capita output level by 1965 . There are 56 countries which fit these criteria and for which data are available. Of these 56 countries, all but four managed to double their per capita outputs by 1992. The four exceptions all had protracted armed insurgencies that disrupted their development in the period. ${ }^{4}$

The difference in the length of the doubling period between the sets of late and early entrants to modern economic growth is dramatic. For early entrants, those defined as achieving 10 percent of the 1985 U.S. level before 1950, the median length of the development period is 45

years. For later entrants, those defined as achieving 10 percent of the 1985 U.S. level after 1950, the median length of the development period is 15 years. Why is it that later entrants in the development process have been able to double their standards of living in a far shorter time than earlier developers? This is another important question that a candidate theory of development must answer.

\section{Why Neoclassical Growth Theory Is Not a Theory of Development}

I now turn to the question of whether neoclassical growth theory can account for the large international differences in incomes and the patterns of development discussed in Section 2. The finding is no, unless total factor productivity is permitted to vary across countries at a point in time and to vary in the appropriate way for each country over time.

The neoclassical production function is the cornerstone of the theory and is used in virtually all applied aggregate analyses. Even before the development of neoclassical growth theory, Klein (1953) used a neoclassical production function in his macroeconometric models. The aggregate production function is used in public finance exercises to evaluate the consequences of 
alternative tax policies. [See, for example, Auerbach and Kotlikoff (1987) and Chari, Christiano, and Kehoe (1994).] Jorgenson and Yun (1984), Shoven and Whalley (1984), and many others use multisector generalizations to address policy issues.

A beauty of this simple construct is that it accounts for the balanced growth that has characterized the U.S. economy for nearly two centuries. Another beauty of this construct is that it deals with well-defined aggregate inputs and outputs. A final beauty is that it is based upon a lot of theory. The aggregate production function specifies maximum output given the quantities of the inputs. If the plant size needed to realize all the economies of scale is small relative to total output and if entry and exit is permitted, profit maximization results in output being maximized given the aggregate factor inputs. Thus, this theory is a theory of the income side of national income and product accounts (NIPA) as well as a theory of production.

For the growth model to be a theory of the international relative income differences, the size of per worker capital stocks across countries must account for differences in output per hour worked, because with this theory, technology is common across countries. Rich countries are rich because they have accumulated large per worker stocks of capital. Differences in stocks of capital are the result of differences in past savings rates. If savings rates are constant, the country with a higher savings rate will have a higher per worker output.

In evaluating the neoclassical growth model as a theory of international income differences, I will restrict the model to be consistent with a set of growth facts that hold over time and across countries. These facts deal with ratios of nominal quantities, so there are no index number problems. One fact is the constancy of factor income shares over time and across countries. In estimating labor share, I assign wage and salary income to labor. I use Kravis' (1959) economywide assumption to assign a fraction of indirect business taxes and sole proprietors' income to 
labor. With this economywide assumption, the share of these components that are labor income is assumed to be the same as for the economy as a whole. The labor income share in the United States has fluctuated about 70 percent, while the real wage has increased steadily. The time series evidence is that the labor share does not vary with the level of income. Gollin (1997) presents cross sectional evidence that the labor share and the level of development are unrelated as well. He finds, using the same income assignment rules that I used, that labor shares are concentrated at about 70 percent across countries with no relation to the level of development. An implication of this fact is that the real wage is roughly proportional to per worker output.

Another fact is that the capital-output ratio with current domestic prices is about 5 percent, independent of per worker output. The average return on capital is estimated as follows. An estimate of total return on capital and land is obtained by summing corporate profits, rental income, net interest income, and 30 percent of proprietors' income. This sum is then divided by the value of private capital and land to obtain the average return. Because rents to consumer durables are not imputed in the NIPA, consumer durables are not included in the stock of private capital.

These facts dictate the choice of a Cobb-Douglas production function with its unit elasticity of substitution between capital and labor services. If the elasticity were not unity, factor share would be related to per worker output. When the Cobb-Douglas production function is used, the growth model specifies per worker output $\mathrm{y}$ as a function of per worker capital $\mathrm{k}$ as follows:

$$
\mathrm{c}_{\mathrm{t}}+\mathrm{x}_{\mathrm{t}} \leq \mathrm{y}_{\mathrm{t}}=\mathrm{A}(1+\gamma)^{\mathrm{t}(1-\theta)} \mathrm{k}_{\mathrm{t}}^{\theta},
$$

where $0<\theta<1$ is the capital share parameter, $\gamma(1-\theta)>0$ is the rate of growth of total factor productivity, $\mathrm{c}$ is per worker consumption, and $\mathrm{x}$ is per worker gross capital formation. The law of motion of the capital stock is 


$$
\mathrm{k}_{\mathrm{t}+1}=(1-\delta) \mathrm{k}_{\mathrm{t}}+\mathrm{x}_{\mathrm{t}},
$$

where $0<\delta<1$.

\section{Savings Rates and Steady-State Income}

An implication of the growth model is that the relative steady-state income level is determined by the savings rate, which might vary for a number of policy-related reasons such as the nature of the tax system. A question, then, is whether differences in gross savings rates across countries can account for a significant part of the differences in levels of development. If the answer to this question is no, there is no reason to proceed to the question of why savings rates differ.

To address the question of whether differences in savings rates can account for differences in per worker incomes across countries, I use the neoclassical production function and assume population growth rate $\eta$. If the gross savings rate is $\mathrm{s}$, (per worker) output will converge to

$$
\mathrm{y}_{\mathrm{t}}=\mathrm{A}(1+\gamma)^{\mathrm{t}}[\mathrm{s} /(\delta+\gamma+\eta)]^{\theta /(1-\theta)} .
$$

Given that labor shares are about 70 percent and that a reasonable value for land share is 5 percent, I estimate $\theta$ to be 0.25 . The steady-state growth rate for total output is $\gamma+\eta$, which I assume to be 3 percent, the approximate value for the United States in the postwar period. Calibrating to the depreciation share of gross domestic product (GDP) yields a value of 0.05 for $\delta$. Table 3 reports relative steady-state levels of output for this value of $\theta$ as a function of the savings rates.

The empirical evidence does not support the proposition that rich countries are rich because they save a higher fraction of their output. The International Monetary Fund (IMF) (vari- 
ous years) reports that, on average, investment as a percentage of GDP is sometimes higher in the rich countries than in the poor countries and is sometimes lower. It is higher in the rich countries every year in the $1960-74$ period. ${ }^{5}$ Just the reverse is true in the $1975-92$ period. During the latter period, the rich countries were investing a smaller fraction of their total product than the poor countries. The average investment rates were near 20 percent for both sets of countries for every year. Differences in the fraction of product invested do not account for differences in international per capita incomes.

\section{What About Mismeasured Capital?}

With this model and common technology across countries, except for tax and other distortions, the price of investment goods relative to consumption goods should be constant across countries. Summers and Heston (1988) find that this is not the case. Easterly (1993), Jones (1994), and Restuccia and Urrutia (1996) document that the prices of investment goods in terms of consumption goods are substantially higher in poor countries. They find that the relative price of investment goods is much higher in poor countries. This has led some to conclude that capitaloutput ratios are smaller in the poor countries and that this can account for a significant part of international income differences. ${ }^{6}$

Defining the stock of capital is conceptually problematic, and measuring the defined concept is difficult in practice. The procedure used by Summers and Heston (1988) to construct capital stocks is as follows. They use price data collected in United Nations International Price Comparison Programme benchmark studies. In a benchmark study, price data are sought for about 1500 commodities of which about a quarter are investment goods. For rich countries, the actual number of prices collected in a study is about 1,110 , and for a poor country, from 400 to 700. The Summers (1973) method is used to construct a purchasing power parity index for each 
category of goods. With this method, if all prices are present, it comes down to using geometric averages of prices to construct price indexes. To construct capital stocks, U.S. useful lives and the perpetual inventory method are used for each of five broad categories of investment goods. The aggregate capital stock is the sum of these five stocks.

There are a number of potential problems. Useful lives are probably longer in poor countries given that the price of maintenance is low in poor countries (Heston and Summers 1996). In addition, with exchange rates, the reason the price of investment goods relative to consumption goods is so much higher in poor countries is that consumption goods are cheap in poor countries and not that investment goods are expensive. On the one hand, investment goods cost about 30 percent more in the poorest countries than they do in the richest countries. On the other hand, consumption goods cost two or three times more in the richest countries than they do in the poorest countries. This suggests that nontradable consumption goods and services are important in accounting for the big difference in explaining why the relative prices of investment goods are so much higher in poor countries.

Even when the Summers and Heston (1991) numbers are taken as adequate measures of the capital service inputs and the outputs, and they are the best available, differences in investment-output ratios account for little of the difference in income per worker output. To see this, I compute how much variation in per worker output there would be if the capital-output ratio were equal across countries, and I compare this to actual variation. This eliminates the effects of differences in the investment-output ratios on steady-state output and leaves only the effects of differences in total factor productivity.

In this exercise, only countries that have participated in at least one International Price Comparison Programme benchmark study, that is, countries for which some prices were col- 
lected for at least one year, and which had a population exceeding 1 million in 1985 are used. The size of the sample is 57 . The important finding is that the standard deviation of the logarithm of per worker output is reduced by only 11 percent. With these calculations, differences in capital that are due to differences in investment share of total product account for 11 percent of the differences, while differences in total factor productivity account for 89 percent. I conclude that even if international, rather than domestic, prices are used, differences in investment share of product account for little of the differences in per worker output. What are important are total factor productivity differences.

\section{What About Missing Capital?}

These IMF statistics are for investment in physical capital. That is not the only form of capital. If other forms of capital are sufficiently important, arbitrarily small differences in savings rates give rise to arbitrarily large differences in steady-state per capita incomes. The NIPA systematically understates the proportion of resources devoted to investment activities. A redefinition of income and product is necessary that expands beyond tangible capital to include all investments. Investment in training people and investment in research and development are part of generic capital. The training component of investment is a big number. From the point of view of economic theory, this investment includes the foregone wages of individuals in technical school as well as the direct costs of providing the training. It includes on-the-job training costs as well. Evidence in support of the importance of on-the-job training is the importance of experience in wage equations. The fraction of variance in wages accounted for by experience is greater than the fraction accounted for by the years-of-schooling variables in the wage equations. This suggests that human capital is being produced in the market sector. Another possibly important form of intangible capital is firm-specific learning-by-doing. Lucas (1988), Stokey (1988), and Young 
(1991) all view learning-by-doing as important and have constructed development models where it plays a key role. Still another form of capital is organization capital. Organizations become better at production through investment of time of members in developing better procedures. I think the value of all these unmeasured investments could well be as much as one-third of GDP. To see if adding intangible capital can make the neoclassical growth model a theory of development, I use an aggregate production function with an intangible capital input as well as labor and tangible capital inputs. The per capita aggregate production function that I use is simply

$$
\mathrm{c}_{\mathrm{t}}+\mathrm{x}_{\mathrm{kt}}+\mathrm{x}_{\mathrm{zt}} \leq \mathrm{y}_{\mathrm{t}}=\mathrm{A}(1+\gamma)^{(1-\theta-\phi) t} \mathrm{k}_{\mathrm{t}}^{\theta} \mathrm{z}_{\mathrm{t}}^{\varphi},
$$

where $\theta+\varphi<1$ is capital share, $x_{k}$ is investment in physical capital, and $x_{z}$ is investment in intangible capital. Labor and land share is $1-\theta-\varphi$. The capital stocks are assumed to evolve according to

$$
\begin{aligned}
& \mathrm{k}_{\mathrm{t}+1}=(1-\delta) \mathrm{k}_{\mathrm{t}}+\mathrm{x}_{\mathrm{kt}} \\
& \mathrm{z}_{\mathrm{t}+1}=(1-\delta) \mathrm{z}_{\mathrm{t}}+\mathrm{x}_{\mathrm{zt}} .
\end{aligned}
$$

If savings rates are constant, that is, the ratios of investments to total product y are constant, this economy will converge to a steady-state growth path with all variables growing at rate $\gamma$.

\section{Calibrating the Model to U.S. Growth Facts}

Comparisons between model economies and real economies should be made across identical statistics. This leads to the principle that if data are reported according to a particular set of accounting conventions, data for the model economy should be reported according to these same conventions. Investments that are expensed, and some investments made by businesses are ex- 
pensed, are not part of GDP with standard NIPA definitions. When the NIPA GDP for the actual economy is compared with a statistic for some model economy, that statistic should be the NIPA GDP of the model economy. This issue turns out to be critical in evaluating the neoclassical growth model as a theory of international income differences if unreported investment is large.

Given the parameter $\varphi$ and a return on intangible capital equal to the return on tangible capital, this model can be calibrated to reported statistics, even though the magnitude of the unmeasured investment is not known. I start the calibration by reorganizing the NIPA data according to this theoretical framework. One issue is how to deal with the government. On the product side, I set consumption equal to the sum of private and public consumption and tangible investment equal to the sum of private and public tangible investment. I treat the services of government capital as an intermediate good to the business sector, that is, the services of roads and government buildings. Depreciation is the sum of the depreciation of private capital and my imputation of depreciation on public capital. The final adjustment is that I follow the United Nations rather than the United States NIPA system and assume borrowers rather than lenders implicitly purchase the financial intermediation services. This reduces net interest income and consumption by equal amounts. With these adjustments, the statistics used in the calibration are a 0.20 ratio of investment to the NIPA GDP, a 5 percent real return, a 5 percent depreciation rate on physical capital, a 1.2 percent population growth rate, and a 1.8 percent real consumption growth rate. These are the approximate averages for the United States in the last half of the twentieth century. What are reported in the NIPA are $\mathrm{c}$ and $\mathrm{x}_{\mathrm{k}}$ on the product side and claims against this product on the income side. The $\mathrm{x}_{\mathrm{z}}$ part of product is not part of the NIPA GDP. Given an amount of unreported product, there must be an equal amount of unreported income. Who receives this income is not clear. For non-firm-specific human capital, theory suggests that it is 
part of the income of the individual receiving the training. More generally, for firm-specific investments, theory provides little guidance as to how this income is divided among the firm's stakeholders. Consequently, reported factor income shares cannot be used in this calibration.

Another issue is at what rate this intangible capital $\mathrm{z}$ depreciates. Without measures of the investment in this form of capital and measures of the market value of this asset, any selected depreciation rate is pretty much a guess. Fortunately, the results reported here are not sensitive to the assumed depreciation rate, and for purposes of these quantitative exercises, I will simply assume that both forms of capital depreciate at the same rate $\delta$. I emphasize again that $y$ is not the GDP reported in the NIPA. It includes investment in intangible capital and is significantly larger than reported GDP. Just how much larger is subject to debate.

I will go through the calibration exercise in some detail because, with the unreported investment in intangible capital, it is not a standard calibration exercise. Given $\varphi$, U.S. steady-state growth observations determine all the other parameters and the values of both $\mathrm{x}_{\mathrm{z}}$ and $\mathrm{z}$. The following five necessary steady-state conditions, along with the specified observation, determine the parameters $(\delta, \gamma, \eta, \theta, A)$ :

$$
\begin{gathered}
r+\delta=\theta A k^{(\theta-1)} z^{\varphi} \\
r+\delta=\phi A^{\theta} z^{(\varphi-1)} \\
c+x_{k}+x_{z}=y=A k^{\theta} z^{\varphi} \\
x_{k}=(\gamma+\eta+\delta) k \\
x_{z}=(\gamma+\eta+\delta) z .
\end{gathered}
$$


The first two conditions are just the profit-maximizing conditions that marginal products equal rental prices. The third is the aggregate production constraint. The last two are the condition that investment is such that per capita stocks grow at rate $\gamma$.

Calibration proceeds as follows. Measured output, $\mathrm{y}_{\mathrm{m}}=\mathrm{x}_{\mathrm{k}}+\mathrm{c}$, is normalized to be 1.00 . This implies that $\mathrm{x}_{\mathrm{k}}=0.20$ and $\mathrm{c}=0.80$. By direct calibration, the population growth rate $\eta=$ 0.012 and the per capita growth rate $\gamma=0.018$. These numbers, along with the datum $\mathrm{k} / \mathrm{y}_{\mathrm{m}}=$ 2.5 and condition (3.10), imply that $\delta=0.05$.

Remaining to be determined are $x_{z}, z, y$, and $\theta$. From condition (3.8) and the production function, it follows that

$$
\mathrm{y}=(\mathrm{r}+\delta) \mathrm{z} / \varphi
$$

Given the datum $r=0.05$ and the values of $\delta$ and $\phi$, this equation, along with conditions (3.9) and (3.11), can be solved for $y, x_{z}$, and $z$. This determines the values of the unreported variables.

The only parameters still to be determined are $\theta$ and A. Parameter $\theta$ can be determined by using the facts that physical capital share of gross income, that is, income plus depreciation, is $\theta$ and that the capital rental price is $r+\delta$. These facts imply the equation $\theta y=(r+\delta) k$, which can be solved for $\theta$. Finally, A can be calculated using the production function, the values of the other parameters, and the values of the capital stocks $\mathrm{k}$ and $\mathrm{z}$. This completes the calibration.

Table 4 reports the implied size of intangible investment relative to the NIPA GDP for selected values of the intangible capital share parameter $\varphi$. The finding is that this unreported investment must be large if $\varphi$ is large. A value of 0.30 for $x_{z} /\left(x_{k}+c\right)$ is the high end of the plausible range. The 67 percent number associated with the $\varphi=0.50$ share parameter is much too 
large. The 127 percent number associated with $\phi=0.70$ is ridiculous. It is not reasonable to assume a share parameter much above 0.30 .

I now explore how savings rates affect steady-state incomes with different assumptions for the value of $\varphi$. To address this question, I drop the requirement that the return on intangible capital investment be 5 percent; that is, I do not require condition (3.8) to hold. In its place, I calibrate the model to different steady-state $x_{z} /\left(c+x_{k}\right)$ ratios for selected values of $\varphi$. Table 5 summarizes the results if $\varphi=0.30$ and $\varphi=0.50$.

The steady-state effects of lower investment rates in intangible capital are not small in an absolute sense, but they are small relative to international income differences. Even if $\varphi=0.50$ and intangible investment as a percentage of output is reduced from 67 percent to 8 percent, output is reduced by a factor of only two. Further, the resulting return on investment in intangible capital is increased to an annual rate of 47 percent, which is a high return on investment.

This leads me to conclude that the neoclassical growth model augmented to include intangible capital is not a theory of international income differences. It fails for two reasons. One is that investment in intangible capital must be at least as large as GDP for investment shares to have sufficiently large consequences for steady-state output. The other is that if intangible investment shares of measured product are small enough to produce differences in per capita income of the magnitude observed in, say, 1985, the return on intangible capital investment must be huge in poor countries.

\section{A Two-Sector Model}

With the assumed neoclassical production technology, the prices of the investment good and the consumption good, absent corners, are equal in equilibrium. In fact, the relative price of durable goods has fallen over time. ${ }^{7}$ For the purposes that I use the model and the statistics to 
which I match the structure, this is not a problem. All the conclusions hold for a two-sector model in which technology change is more rapid in the durable-good sector, provided that the capital share is not much higher in the capital good producing sector than it is in the consumption good producing sector. With such a technology, the relative price of capital goods, in which one unit of capital provides one unit of capital services, declines secularly.

The following two-sector model establishes this point. The consumption good sector has the production function

$$
\mathrm{c}_{\mathrm{t}}=\mathrm{Ak}_{\mathrm{t}}^{\theta} \text {. }
$$

The investment good sector has the production function

$$
\mathrm{x}_{\mathrm{t}}=\mathrm{A}(1+\gamma)^{\mathrm{t}(1-\theta) / \theta} \mathrm{k}_{\mathrm{t}}^{\theta} .
$$

All variables are per worker. The capital share parameter is assumed to be the same for these two sectors as capital and labor shares of value added vary little across highly aggregated industrial sectors. In this world, all the technology change is in the investment good sector, and none is in the consumption good sector. As before, capital depreciates at rate $\delta$, so

$$
\mathrm{k}_{\mathrm{t}+1}=(1-\delta) \mathrm{k}_{\mathrm{t}}+\mathrm{x}_{\mathrm{t}} .
$$

If the savings rate is constant, that is, the ratio of the value of investment to output in current prices is constant, the economy converges to a growth path in which c grows at the constant rate $\gamma$ and both $\mathrm{x}$ and $\mathrm{k}$ grow at the rate $\gamma / \theta$. The price of the investment good relative to the consumption good declines at the rate $\gamma / \theta-\gamma$. In the steady state, the value of investment as a share of output is a constant share of output. Thus, this technology is consistent with the U.S. growth fact that investment share has been more or less constant in current prices, even though 
the price of investment has declined relative to the price of consumption In constant prices, of course, investment share of product has increased over the last 50 years.

\section{Adding a Human Capital Production Sector}

If capital-labor ratios are approximately the same across sectors, the single and the multisector model behave essentially the same way, at least relative to the development issues being addressed here. If the capital goods producing sector is highly capital intensive, however, differences in savings rates will have large level effects. Rebelo's (1991) endogenous growth model establishes this result. The sector producing physical capital is not highly capital intensive. However, the sector producing human capital is highly intensive in the human capital input. This observation is probably what led Lucas (1988) to add a nonmarket, human capital producing sector, which is intensive in the human capital input. If this is the case, differences in savings rates appropriately defined might have large consequences for steady-state levels of income.

In this section, I explore a variant of the Lucas (1988) model that focuses on training that increases the effective units of labor services an individual can supply per unit of time allocated to the market sector. The model differs from that of Lucas in that savings rates determine relative steady-state income levels and not growth rates. Another difference is the definition of human capital. My definition is narrower than the one employed by Lucas, but is consistent with the definition used by some development economists who view differences in the investment in training as being capable of accounting for international differences in per capita incomes. ${ }^{8}$

Individuals in this model economy allocate some fraction of their time $\mathrm{s}_{\mathrm{h}}$ to enhancing their human capital and the remainder $1-\mathrm{s}_{\mathrm{h}}$ to market production. There is a standard neoclassical production technology, namely, 


$$
\begin{gathered}
\mathrm{c}_{\mathrm{t}}+\mathrm{x}_{\mathrm{t}}=\mathrm{y}_{\mathrm{t}} \leq \mathrm{Ak}^{\theta}\left[\left(1-\mathrm{s}_{\mathrm{ht}}\right) \mathrm{h}_{\mathrm{t}}\right]^{(1-\theta)} \\
\mathrm{k}_{\mathrm{t}+1}=\mathrm{x}_{\mathrm{t}}+\left(1-\delta_{\mathrm{k}}\right) \mathrm{k}_{\mathrm{t}},
\end{gathered}
$$

for the consumption and tangible capital production sectors. ${ }^{9}$ Here $\left(1-s_{h}\right) h$ is human capital services allocated to the production of market goods. The key sector is the human capital production sector, which has the following production function: ${ }^{10}$

$$
\mathrm{h}_{\mathrm{t}+1}-\left(1-\delta_{\mathrm{h}}\right) \mathrm{h}_{\mathrm{t}}=(1+\gamma)^{(1-\sigma) \mathrm{t}}\left(\mathrm{s}_{\mathrm{ht}} \mathrm{h}_{\mathrm{t}}\right)^{\sigma} \mathrm{t} .
$$

The idea that growth in useable knowledge leads to increased returns on the investment in human capital is, I think, a plausible one. The knowledge acquired per unit of time is greater if the stock of publicly available knowledge is larger. The information in a library today surely exceeds that contained in libraries 100 years ago.

\section{Savings Rates and Steady-State Income}

A constant savings rate policy in this world is defined as one for which both the fraction of human capital allocated to human capital production $s_{h}$ and the physical capital savings rate $\mathrm{s}_{\mathrm{k}}=\mathrm{x} / \mathrm{y}$ are constant. The steady-state growth rate of an economy with this technology is $\gamma$ for any constant savings rate policy. Given that $s_{k}$ does not vary systematically with the level of development, it is set in such a way that it keeps the steady-state physical investment to the NIPA GDP constant. The key parameter for determining how the fraction of time allocated to human capital investment affects steady-state output is $\sigma$, the exponent in the human capital production function. If it is sufficiently near one, any given difference in the savings rate $\mathrm{s}_{\mathrm{h}}$ leads to arbitrarily large differences in steady-state outputs. 
This model can be calibrated to the U.S. growth facts, given values for the human capital depreciation rate $\delta_{\mathrm{h}}$ and the curvature parameter $\sigma$ in the human capital production function.

The results are not sensitive to the value of $\delta_{\mathrm{h}}$ selected; therefore, I simply selected $\delta_{\mathrm{h}}=\delta$. The results are sensitive to the value of $\sigma$ selected. Given that this is the case, the model is calibrated for a number of values of $\sigma$ to determine if for any value of $\sigma$ the implications of the model are conceivable.

Table 6 reports $s_{h}$, the fraction of time allocated to human capital investment, for selected values of $\sigma$. As can be seen, the larger is $\sigma$, the larger is this fraction. For values of $\sigma$ greater than 0.60 , as much time is allocated to training as is allocated to market production. Such numbers are well in excess of the numbers reported in time allocation studies.

The question addressed is whether plausible variations in $\mathrm{s}_{\mathrm{h}}$ can account for the large differences in international incomes for any value of $\sigma$. To address this question, the model is first calibrated to the same set of observations as the model of the previous section. Next, the restriction that the return on human capital is 5 percent is dropped, and $s_{h}$ is varied. Table 7 summarizes the results of these numerical exercises. The table reports steady-state income and returns on human capital investment as a function of $\mathrm{s}_{\mathrm{h}}$ for two values of $\sigma$.

If $\sigma=0.60$, the implied time allocated to producing human capital is as large as the time allocated to producing market goods. This number is larger than what is plausible. Even with this number, if the fraction of time allocated to human capital production is reduced from 0.48 to 0.12 , output decreases by a factor of only five, a number that is only one-fifth of the difference in incomes in the richest and poorest countries. Another problem for this theory is that such a reduction would result in the return on human capital investment being 35 percent in the poorest 
countries as compared to only 5 percent in the richest countries. With such high returns on human capital investment in poor countries, human capital should flow from the rich to the poor countries. In fact, the flow tends to be in the opposite direction. These findings lead me to reject this model as a theory of international income differences.

\section{Evidence of Inefficient Production}

In this section, I review some evidence that there are differences in industry total productivities that are not due to changes in the stock of useable knowledge. One case examines the reasons for productivity differences in the textile industry across countries in 1910 . Another compares industry productivities across the large rich industrial countries with very similar factor endowments. The other two examine the time pattern of an industry productivity and conclude that these movements are not due to new knowledge but are due to changes in work practices.

\section{The Textile Industry}

A dramatic example of technologies being used inefficiently is the textile industry in the early part of the twentieth century. Clark (1987) documents that in 1910, labor productivity in the cotton mills in New England and Canada was seven times higher than in the cotton mills in India. He concludes that these productivity differences were due to the number of looms operated per worker, and not to the technologies or the education and physical strength of the workers. The reason for most of the difference in the number of looms operated per worker was not the difference in factor prices. But why did the number of looms operated per worker vary across regions? In all but the most productive region, some employers wanted their workers to operate more looms. Evidence of this is found in the conflicts between employers and employees over the number of machines employees operated. In India, this conflict was two versus one loom per 
weaver; in Russia, three versus two; in France and Mexico, four versus three; and in England, six versus four.

Wolcott (1994) presents evidence that incentives and resistance do matter for productivity. She examines differences in labor productivity growth in the cotton mills in India and Japan between 1920 and 1938 and interprets the very different behavior of productivity growth as being the result of differences in the ability of labor to resist employers' attempts to change work practices. In this period, Japanese labor productivity increased by over 120 percent, while Indian productivity increased by only 40 percent. According to Wolcott (1994), these productivity increases were not associated with purchases of more or better equipment. Rather, these increases were achieved by changes in organization that effectively increased the number of machines operated per worker. Her thesis, which matches mine, is that workers in Japan had less incentive and ability to resist employers' attempts to increase the number of machines each employee operated.

The reason resistance was not effective in Japan is that most of the textile workers there were illiterate girls from the provinces between the ages of 15 and 18 . They worked in the mills for only a few years before getting married. These workers were kept separated from each other in dormitories and were sent back to the provinces the one time they organized a strike. In India, in contrast, most of the workers were adult males who spent their entire lifetimes working in that industry. They had greater incentive to resist the adoption of practices that would increase labor productivity and reduce employment given the perceived inelastic demand for the product they produced. Given lifetime tenure and inelastic demand for the product of the industry, increases in production efficiency resulted in workers suffering large capital loss. 


\section{Coal Mining in the United States}

Another example of big productivity movements that appear to be the result of changes in the incentives of workers to resist more efficient work practices is the U.S. subsurface coal mining industry in the 1949-94 period. This sector had a strong union that could, at least in the early part of the period, dictate work practices and, to a significant extent, wages. The behavior of price, output, and productivity strongly suggests that the large movements in productivity were the result of the coal mining union using this power in a way that was in the interest of its members.

Figure 2 plots the real price of coal versus labor productivity and output. One feature of the plot is that the correlation between the real price of coal and productivity is highly negative. Another feature is that the amplitudes of fluctuation of these two variables are large with output per hour varying by a factor of over four and coal's real price by a factor of three. A final feature of the data is that there is relatively little variation in the output of coal with the maximum yearly output being only 1.5 times the minimum yearly output. These observations do not fit with standard supply and demand theory.

Labor productivity increased in the $1949-69$ period by a factor of three, while the real price of coal fell by 40 percent. The reason for this increase in productivity, particularly in the early part of the period, was the introduction of the boring machine to replace the pick and shovel technology. The use of boring machines in coal mining was not a technological innovation. Boring machines were widely used to construct tunnels for many years before their use in coal mining. The use of the boring machine was a proven technology. The reason it was so long before they were used in coal mining was that union contracts explicitly prohibited their use. They were introduced only when their use in coal mining became in the interest of the miners. 
What changed in the late forties and made it in the interest of coal miners to permit the use of this proven technology was that cheap substitutes, namely, oil and natural gas, became available. This is when cheap oil became available from the Middle East, Venezuela, and the Gulf of Mexico. With the availability of low priced oil, if productivity did not increase, many coal mines would be closed. There was an agreement that permitted this more efficient technology to be used. The coal miners subsequently received $\$ 20$ for every ton of coal mined to finance union pension benefits.

In the 1969-78 period, labor productivity fell by one-half. This decline in productivity was not the result of new technical knowledge. The reason for the decline was that the price of coal substitutes in the United States increased, and it became apparent that nuclear energy would not be the promised cheap energy source in the foreseeable future. The breakdown of the cartel of big oil buying companies and the rise of the cartel of oil supplying countries is the reason for the decline in productivity in the coal mines in the 1969-78 period. Apparently, union miners lowered productivity in order to increase the employment of miners. There was a large increase in hours of employment without any increase in output.

The trend in coal productivity reversed itself again in the 1978-94 period. During this period, productivity increased by a factor of over three. My explanation for this increase is that, again, miners had no choice but to permit more efficient work practices. If productivity did not increase, the mines would be closed. One factor in increased productivity was a fall in the price of oil. A more important factor, however, was that subsurface coal mines faced increased competition from nonunionized open pit mines in the western United States. There are two reasons for this increased competition. One is that western coal has a lower sulfur content. With the need to reduce sulfur dioxide (the major contributor to acid rain) in the air, the demand for subsurface 
coal fell. The other reason is that the price of western coal fell with the deregulation of transportation. This further reduced the demand for subsurface mined coal from the eastern United States. This increase in productivity was not primarily the result of new useable knowledge; at least, I know of no innovation that accounts for this large increase. The evidence is strong that the reason productivity increased so much was that the reduction in the demand for coal made it in the interest of subsurface coal miners to permit more efficient work practices.

\section{Relative Productivities Across Countries and Industries}

The United States is the world's most productive nation. It has been since 1890, when it overtook the United Kingdom. However, the United States is not the most productive nation in all industries in all sectors. While value added per worker in service sector industries is uniformly higher in the United States, it is not uniformly higher in manufacturing sector industries. In that sector, Japan is more productive than the United States in a large number of industries. That the United States, overall, is the most productive nation is due to its service sector being much larger than its manufacturing sector in the economy.

Table 8 presents some estimates of value added per worker in a selected set of manufacturing industries in a number of large rich countries. This value added per worker is essentially total factor productivity, because differences in capital per worker are small and account for only a little of the difference in value added per worker. All productivity levels are expressed relative to the U.S. level, which has been normalized to 100. The estimates are from Baily and Gersbach

(1995) and Baily (1993). ${ }^{11}$ As Table 8 shows, industry value added per worker varies a lot among the large rich countries - by a factor as big as three in some industries.

Differences in skills or stocks of human capital of workers, to the extent that they even exist, cannot explain these differences in value added per worker either. Two observations lead 
me to this conclusion. One is that the investigators, after examining the skills of the workers and the skills required for each industry, conclude that workers in each country are qualified to work in their industry in any of the other countries. It is not a matter of the highly productive steelworkers in Japan carrying out sophisticated operations that American and German steelworkers cannot. The other is that if workers in one country are better educated or have a better work ethic than workers in another country, that country should be more productive in all industries in all sectors. This is not the observed pattern.

Differences in stocks of useable knowledge across countries cannot explain these differences in value added per worker. The stock of useable knowledge does not vary much across these countries. Intellectual propriety rights do not effectively reduce the stock of useable knowledge that a country has at its disposal because of licensing agreements and direct investment. Moreover, within the set of large rich countries, there are many multinational corporations operating. Plants of these corporations operated in different countries surely have access to the same knowledge.

The amount of this knowledge that is used can and, indeed, does vary from one country to another. For instance, Ford Europe has failed to adopt Japanese just-in-time production in producing automobiles, but Ford U.S.A. has adopted it. In the beer industry, much of the high technology machinery used in Japanese and U.S. plants is manufactured in Germany. Yet German breweries fail to use these more productive technologies. Why doesn't Ford Europe use the better technology used by Ford U.S.A.? And why don't German brewers use the equipment German firms sell to the more productive U.S. brewers?

Baily and Gersbach (1995) and Baily (1993) point to several constraints in the lower productivity nations that prevent firms in those countries from changing current functions and tasks 
as the reason for why available knowledge is not as fully exploited in some countries. Some of these constraints are imposed by the government and take the form of regulations and laws. German breweries, for example, cannot adopt the better technologies that are used in the United States and Japan, even though the equipment to run those technologies is made in Germany, because of explicit rules and regulations that govern beer production there. Similarly, zoning laws in the United Kingdom, France, and Germany prevent entry by stores with new retailing formats. In other industries, these constraints do not take the form of government regulations and laws. Baily (1993) argues that in the airline industry, the lower productivity in Europe is a result of overstaffing, which cannot be rectified because of union power. These constraints must be part of any theory of total factor productivity.

\section{Concluding Remarks}

The thesis of this paper is that a theory of total factor productivity is needed to understand large international income differences. I have explored whether differences in capital per worker can account for the huge observed differences in output per worker. I conclude that they

cannot. ${ }^{12}$ Adding intangible capital does not make the neoclassical growth model a theory of international income differences. Only if investment in intangible capital is as large as GDP do savings rate differences have important consequences for output per worker. A model with a human capital producing sector fails for similar reasons. The fraction of time allocated to enhancing human capital must be larger than time allocated to market for differences in human capital investment rates to be important. The neoclassical growth model accounts for differences across countries only if total factor productivity differs across countries. 


\section{Why Are Total Factor Productivities Different?}

My candidate for the factor is the strength of the resistance to the adoption of new technologies and to the efficient use of currently operating technologies, and this resistance depends upon the policy arrangement a society employs. What is needed is a theory of how arrangement affects total factor productivity. Introducing game theoretic elements into applied general equilibrium models will almost surely be a crucial part of any such theory. Once there is a successful theory of total factor productivity, the next level of theorizing is to explain why a society chooses the arrangement it does. ${ }^{13}$

I am not the first to emphasize the importance of the effectiveness of resistance to the use of better technologies in understanding economic development. Economic historians, in particular, Mokyr (1990, pp. 209-72), assign a major role to this factor in explaining why modern economic growth, that is, sustained increases in per capita income, began in the West rather than in China and began early in Britain and then spread to its continental neighbors. Mokyr (1990, p. 12) points out the following:

In every society, there are stabilizing forces that protect the status quo.

Some of these forces protect entrenched vested interests that might incur losses if innovations were introduced, others are simply don't-rock-the-boat kinds of forces. Technological creativity needs to overcome these forces.

Mokyr (1990, p. 16) goes on to note that technologically progressive societies are the exception. More often than not, the forces opposing technological progress have been stronger than the forces striving for changes. His view is that technological progress is fragile and can easily be arrested by relatively small external changes. My view is optimistic. If there are decentralized arrangements with dispersion of resources and decision making authority, technological progress 
will continue, total factor productivity will increase, and living standards will continue to increase for the indefinite future. Further, in another hundred years, there will not be the great international income differences. The poor countries will catch up with the rich, which will then be many times richer.

University of Minnesota and Federal Reserve Bank of Minneapolis 
Notes

*I thank the National Science Foundation for financial support and Antoine Martin, Dirk Krueger, and Claustre Bajona-Xandri for excellent research assistance. I also thank Jim Schmitz, Ellen McGrattan, and especially Stephen Parente for constructive criticisms of earlier drafts. The views expressed herein are those of the author and not necessarily those of the Federal Reserve Bank of Minneapolis or the Federal Reserve System.

${ }^{1}$ See Maddison (1991, p. 10) and Bairoch (1993, pp. 101-8).

${ }^{2}$ See Maddison (1991, pp. 11-15).

${ }^{3}$ See Hartwell (1966).

${ }^{4}$ These four countries are Guatemala, El Salvador, Nicaragua, and Papau New Guinea. Papau New Guinea was not an independent country until 1975.

${ }^{5}$ See p. 159 in the IMF 1994 International Financial Statistics Yearbook.

${ }^{6}$ Mankiw, Romer, and Weil (1992) and Chari, Kehoe, and McGrattan (1996) come to this conclusion.

${ }^{7}$ See Greenwood, Hercowitz, and Krusell (1997).

${ }^{8}$ For example, see Barro (1991) and Mankiw, Romer, and Weil (1992). Bils and Klenow (1996) present some empirical evidence that expected growth in output leads to investment in human capital rather than human capital investment leading to growth.

${ }^{9}$ Lucas (1988) also has a human capital externality that results in the human capital services provided by an individual being an increasing function of the human capital levels of co-workers. 
${ }^{10}$ For the Lucas (1988) model, $\sigma=1$. With $\sigma=1$, there must be a multiplicative constant in the human capital production function.

${ }^{11}$ For telecommunications, productivity is measured in terms of number of calls per worker. For commercial banking, productivity is actually measured in terms of an average of three banking functions per worker.

${ }^{12}$ Recently, Hall and Jones (1996) and Klenow and Rodriguez-Clare (1996) estimate countries' total factor productivities and find that they are proportional to the per capita GDP of countries.

${ }^{13}$ Krusell and Ríos-Rull (1996) develop such a model. This model endogenizes society's decision of whether or not to permit the adoption of a better technology. It is in a dynamic equilibrium model with strategic voting by generations. Holmes and Schmitz (1995) develop a general equilibrium model in which free trade reduces the incentive to resistance of a better technology and results in the better technology being adopted. 


\section{REFERENCES}

Auerbach, A. J. and L. J. Kotlikoff, Dynamic Fiscal Policy (Cambridge, U.K.: Cambridge University Press, 1987).

Baily, M. N., "Competition, Regulation, and Efficiency in Service Industries," Brookings Papers on Economic Activity, Microeconomics 2 (1993), 71-130.

Baily, M. N. and H. Gersbach, "Efficiency in Manufacturing and the Need for Global Competition," Brookings Papers on Economic Activity, Microeconomics (1995), 307-347.

Bairoch, P., Economics and World History: Myths and Paradoxes (New York: Harvester Wheatsheaf, 1993).

Barro, R. J., "Economic Growth in a Cross Section of Countries," Quarterly Journal of Economics 106 (1991), 407-443.

Bils, M. and P. J. Klenow, “Does Schooling Cause Growth or the Other Way Around?” mimeo, University of Chicago, 1996.

Chari, V. V., L. J. Christiano, and P. J. Kehoe, “Optimal Fiscal Policy in a Business Cycle Model," Journal of Political Economy 102 (1994), 617-652.

Chari, V. V., P. J. Kehoe, and E. R. McGrattan, “The Poverty of Nations: A Quantitative Exploration,” NBER Working Paper No. 5414, 1996.

Clark, G., "Why Isn't the Whole World Developed? Lessons From the Cotton Mills," Journal of Economic History 47 (1987), 141-173.

Easterly, W., “How Much Do Distortions Affect Growth?” Journal of Monetary Economics 32 (1993), 187-212.

Energy Information Administration, Coal Data (U.S. Department of Energy, 1996). 
Gollin, D., "Getting Income Shares Right: Self Employment, Unincorporated Enterprise, and the Cobb-Douglas Hypothesis,” working paper, 1997.

Greenwood, J., Z. Hercowitz, and P. Krusell, "Macroeconomic Implications of InvestmentSpecific Technological Change," American Economic Review 87 (1997), 342-362.

Hall, R. E. and C. I. Jones, “The Productivity of Nations,” NBER Working Paper No. 5812, 1996.

Hartwell, R., "Markets, Technology and the Structure of Enterprise in the Development of the Eleventh-Century Chinese Iron and Steel Industry," Journal of Economic History 26 (1966), 29-58.

Heston, A. and R. Summers, "International Price and Quantity Comparisons: Potentials and Pitfalls," American Economic Review 86 (1996), 20-24.

Holmes, T. J. and J. A. Schmitz Jr., "Resistance to New Technology and Trade Between Areas," Federal Reserve Bank of Minneapolis Quarterly Review (Winter 1995), 2-17.

International Monetary Fund, (International Financial Statistics Yearbook, various years).

Jones, C. I., "Economic Growth and the Relative Price of Capital," Journal of Monetary Economics 34 (1994), 359-382.

Jorgenson, D. W. and K. Y. Yun, “Tax Policy and Capital Allocation,” Harvard Institute of Economic Research Discussion Paper No. 1107, 1984.

Klein, L. R., A Textbook of Econometrics (Evanston, Ill.: Row, Peterson and Company, 1953).

Klenow, P. J. and A. Rodriguez-Clare, "Economic Growth: A Review Essay,” working paper, 1996.

Kravis, I. B., "Relative Income Shares in Fact and Theory," American Economic Review 49 (1959), 917-949. 
Krusell, P. and J.-V. Ríos-Rull, "Vested Interests in a Positive Theory of Stagnation and Growth," Review of Economic Studies 63 (1996), 301-329.

Kuznets, S., Economic Growth and Structure: Selected Essays by Simon Kuznets (London: Heinemann, 1966).

Lucas, R. E. Jr., "On the Mechanics of Economic Development," Journal of Monetary Economics 22 (1988), 3-42.

Maddison, A., Dynamic Forces in Capitalist Development (Oxford University Press, 1991). , Monitoring the World Economy:1820-1992 (Paris: Organization for Economic and Co-operation Development, 1995).

Mankiw, N. G., D. Romer, and D. Weil, "A Contribution to the Empirics of Economic Growth," Quarterly Journal of Economics 107 (1992), 407-437.

Mokyr, J., The Lever of Riches: Technological Creativity and Economic Progress (New York: Oxford University Press, 1990).

Rebelo, S., "Long-Run Policy Analysis and Long-Run Growth,” Journal of Political Economy 99 (1991), 500-521.

Restuccia, D. and C. Urrutia, "Public Policy, Price Distortions, and Investment Rates," manuscript, University of Minnesota, 1996.

Shoven, J. B. and J. Whalley, “Applied General-Equilibrium Models of Taxation and International Trade: An Introduction and Survey," Journal of Economic Literature 22 (1984), $1007-1051$.

Solow, R. M., "Technical Change and the Aggregate Production Function," Review of Economics and Statistics 39 (1957), 312-320. 
Stokey, N. L., "Learning by Doing and the Introduction of New Goods," Journal of Political Economy 96 (1988), 701-717.

Summers, R., “International Price Comparisons Based Upon Incomplete Data,” Review of Income and Wealth 19 (1973), 1-16.

Summers, R. and A. Heston, “A New Set of International Comparisons of Real Product and Price Levels: Estimates for 130 Countries, 1950-1985," Review of Income and Wealth 34 (1988), 1-25. and , The Penn World Table (Mark 5): An Expanded Set of International Comparisons, 1950-1988," Quarterly Journal of Economics 106 (1991), 327-368. Wolcott, S., "The Perils of Lifetime Employment Systems: Productivity Advance in the Indian and Japanese Textile Industries, 1920-1938," Journal of Economic History 54 (1994), $307-324$.

Young, A., "Learning by Doing and the Dynamic Effects of International Trade," Quarterly Journal of Economics 106 (1991), 369-405. 
Table 1: The West versus the East

Per Capita Output (U.S. dollars, 1990 international prices)

\begin{tabular}{cccc} 
Year & West & East & West/East \\
\hline 1820 & 1,140 & 540 & 2.1 \\
1870 & 1,880 & 560 & 3.3 \\
1900 & 2,870 & 680 & 4.2 \\
1913 & 3,590 & 740 & 4.8 \\
1950 & 5,450 & 727 & 7.5 \\
1973 & 10,930 & 1,670 & 6.5 \\
1989 & 13,980 & 2,970 & 4.7 \\
1992 & 13,790 & 3,240 & 4.3 \\
\hline \hline
\end{tabular}

Source: Maddison (1991) 
Table 2: Ratio of West to East Per Capita Income

\begin{tabular}{cc} 
Year & West/East \\
\hline 1960 & 7.3 \\
1973 & 7.3 \\
1989 & 5.7 \\
1992 & 5.2 \\
1995 & 3.7 \\
\hline \hline
\end{tabular}

Source: Summers and Heston (1991) 
Table 3: Steady-State Effects of Savings Rates on Income Levels

\begin{tabular}{cc} 
Savings Rate & Relative Income Level (\%) \\
\hline \hline .10 & .79 \\
.20 & 1.00 \\
.30 & 1.15 \\
.40 & .26 \\
\hline \hline
\end{tabular}


Table 4: Implied Intangible Investment and Parameter $\theta$

\begin{tabular}{ccc}
$\begin{array}{c}\text { Intangible Capital Share } \\
\text { Parameter } \varphi\end{array}$ & $\begin{array}{c}\text { Implied Physical } \\
\text { Capital Share } \\
\text { Parameter } \theta\end{array}$ & $\begin{array}{c}\text { Implied Investment in } \\
\text { Intangible Capital as a } \\
\text { Fraction of NIPA GDP }\end{array}$ \\
\hline \hline 0.00 & 0.25 & 0.00 \\
0.30 & 0.19 & 0.32 \\
0.50 & 0.15 & 0.67 \\
0.70 & 0.11 & 1.27 \\
\hline \hline
\end{tabular}


Table 5: Effects of a Lower Intangible Capital Investment Rate on Steady-State GDP and Intangible Capital Return

$$
\varphi=0.30
$$

\begin{tabular}{ccc}
\hline \hline $\begin{array}{c}\text { Intangible Capital } \\
\text { Investment Rate } \\
\mathrm{x}_{\mathrm{z}} /\left(\mathrm{c}+\mathrm{x}_{\mathrm{k}}\right)\end{array}$ & $\begin{array}{c}\text { Relative GDP } \\
\left(\mathrm{c}+\mathrm{x}_{\mathrm{k}}\right)\end{array}$ & $\begin{array}{c}\text { Return on Intangible } \\
\text { Capital Investment } \\
\mathrm{x}_{\mathrm{z}}\end{array}$ \\
\hline 0.32 & 1.00 & $5 \%$ \\
0.16 & 0.82 & $13 \%$ \\
0.08 & 0.61 & $28 \%$ \\
0.04 & 0.43 & $58 \%$ \\
\hline \hline
\end{tabular}

$$
\varphi=0.50
$$

\begin{tabular}{ccc}
\hline $\begin{array}{c}\text { Intangible Capital } \\
\text { Investment Rate } \\
\mathrm{x}_{\mathrm{z}} /\left(\mathrm{c}+\mathrm{x}_{\mathrm{k}}\right)\end{array}$ & $\begin{array}{c}\text { Relative GDP } \\
\left(\mathrm{c}+\mathrm{x}_{\mathrm{k}}\right)\end{array}$ & $\begin{array}{c}\text { Return on Intangible } \\
\text { Capital Investment } \\
\mathrm{x}_{\mathrm{z}}\end{array}$ \\
\hline 0.67 & 1.00 & $5 \%$ \\
0.33 & 0.64 & $11 \%$ \\
0.17 & 0.23 & $23 \%$ \\
0.08 & 0.15 & $47 \%$ \\
\hline \hline
\end{tabular}


Table 6: Implied Time Allocated to Human Capital Accumulation for Different $\sigma$

\begin{tabular}{cc} 
Value of $\sigma$ & $\begin{array}{c}\text { Implied Fraction of } \\
\text { Time } \mathrm{s}_{\mathrm{h}}\end{array}$ \\
\hline 0.00 & 0.00 \\
0.20 & 0.16 \\
0.30 & 0.24 \\
0.40 & 0.32 \\
0.50 & 0.40 \\
0.60 & 0.48 \\
0.70 & 0.56 \\
0.80 & 0.64 \\
0.90 & 0.72 \\
\hline \hline
\end{tabular}


Table 7: Effects of Time Allocated to Human Capital Investment on Steady-State Output

$$
\sigma=0.30
$$

\begin{tabular}{ccc}
\hline \hline $\begin{array}{c}\mathrm{x}_{\mathrm{z}} \text { as Share } \\
\text { of GDP }\end{array}$ & $\begin{array}{c}\text { Relative } \\
\text { GDP }\end{array}$ & $\begin{array}{c}\text { Return on } \mathrm{h} \\
\text { Investment }\end{array}$ \\
\hline 0.24 & 1.00 & $5 \%$ \\
0.12 & 0.86 & $15 \%$ \\
0.06 & 0.76 & $35 \%$ \\
\hline \hline
\end{tabular}

\begin{tabular}{ccc}
\multicolumn{3}{c}{$\sigma=0.60$} \\
\hline $\begin{array}{c}\mathrm{x}_{\mathrm{z}} \text { as Share } \\
\text { of GDP }\end{array}$ & $\begin{array}{c}\text { Relative } \\
\text { GDP }\end{array}$ & $\begin{array}{c}\text { Return on } \mathrm{h} \\
\text { Investment }\end{array}$ \\
\hline 0.48 & 1.00 & $5 \%$ \\
0.24 & 0.52 & $15 \%$ \\
0.12 & 0.21 & $35 \%$ \\
\hline \hline
\end{tabular}


Table 8: Value Added Per Worker-Manufacturing Industries

\begin{tabular}{lcc} 
Industry & Japan & Germany \\
\hline \hline Automobiles & 116 & 66 \\
Automobile Parts & 124 & 76 \\
Metal Working & 119 & 100 \\
Steel & 145 & 100 \\
Computer & 95 & 89 \\
Consumer Electronics & 115 & 62 \\
Food & 33 & 76 \\
Beer & 69 & 44 \\
Soap and Detergent & 94 & 76 \\
\hline \hline
\end{tabular}

Value Added Per Worker-Service Industries

\begin{tabular}{lcccc} 
Industry & Japan & Germany & U.K. & France \\
\hline \hline Retailing & 44 & 96 & 82 & 69 \\
Telecommunications & 66 & 50 & 38 & 56 \\
Banking & - & 68 & 64 & - \\
\hline \hline
\end{tabular}


Figure 1

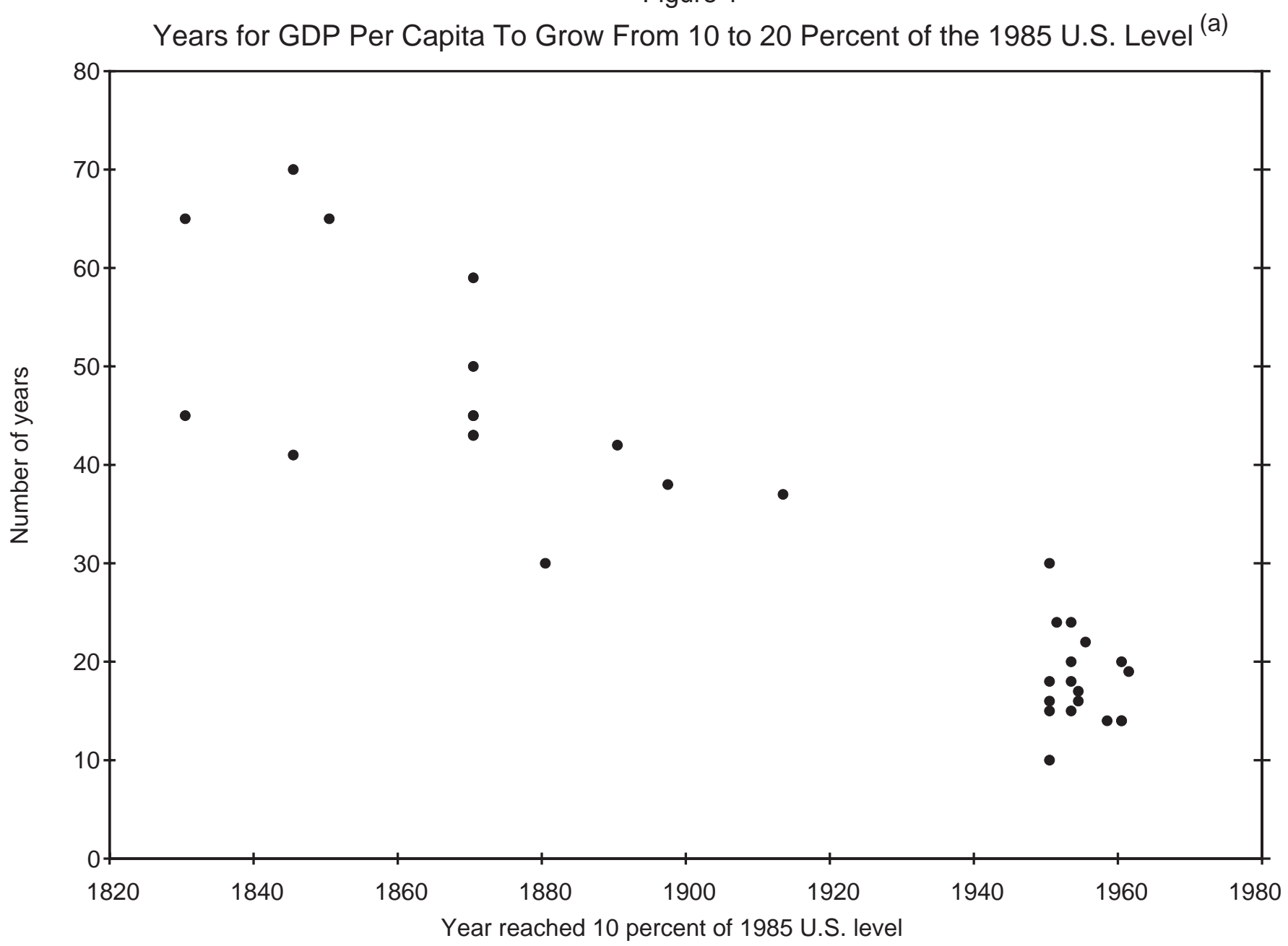

(a) Because of the wartime interruptions, I used the period that Austria went from .08 to .161985 U.S. per capita GDP, the period that Germany went from .05 to .10 of 1985 U.S. per capita GDP, and the period that Italy went from .075 to .15 of 1985 U.S. per capita GDP.

Sources: Maddison (1991) and Summers and Heston (1991) 


\section{U.S. Subsurface Mining, 1949 - 1994}

Figure $2 \mathrm{a}$

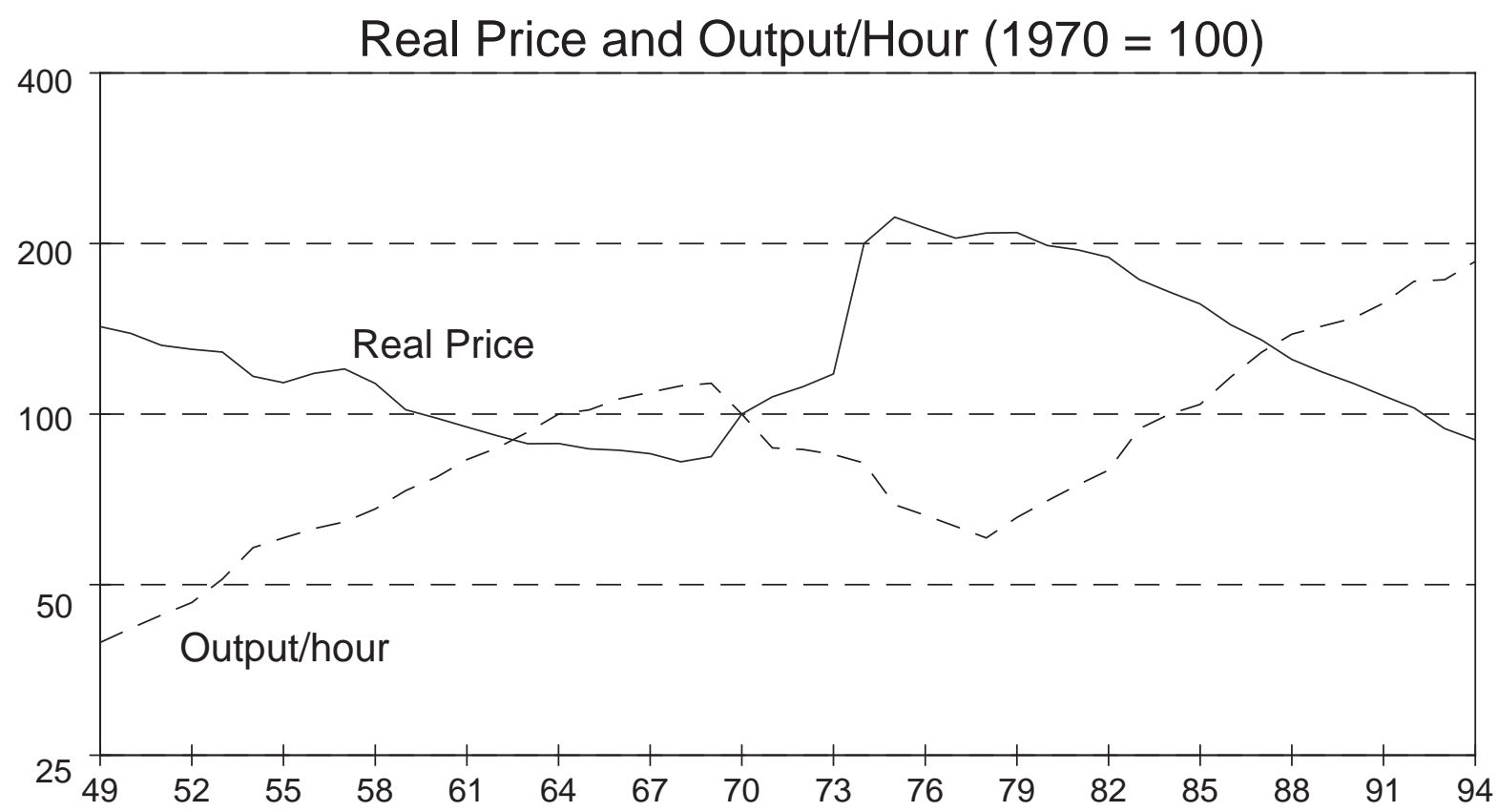

Figure $2 b$

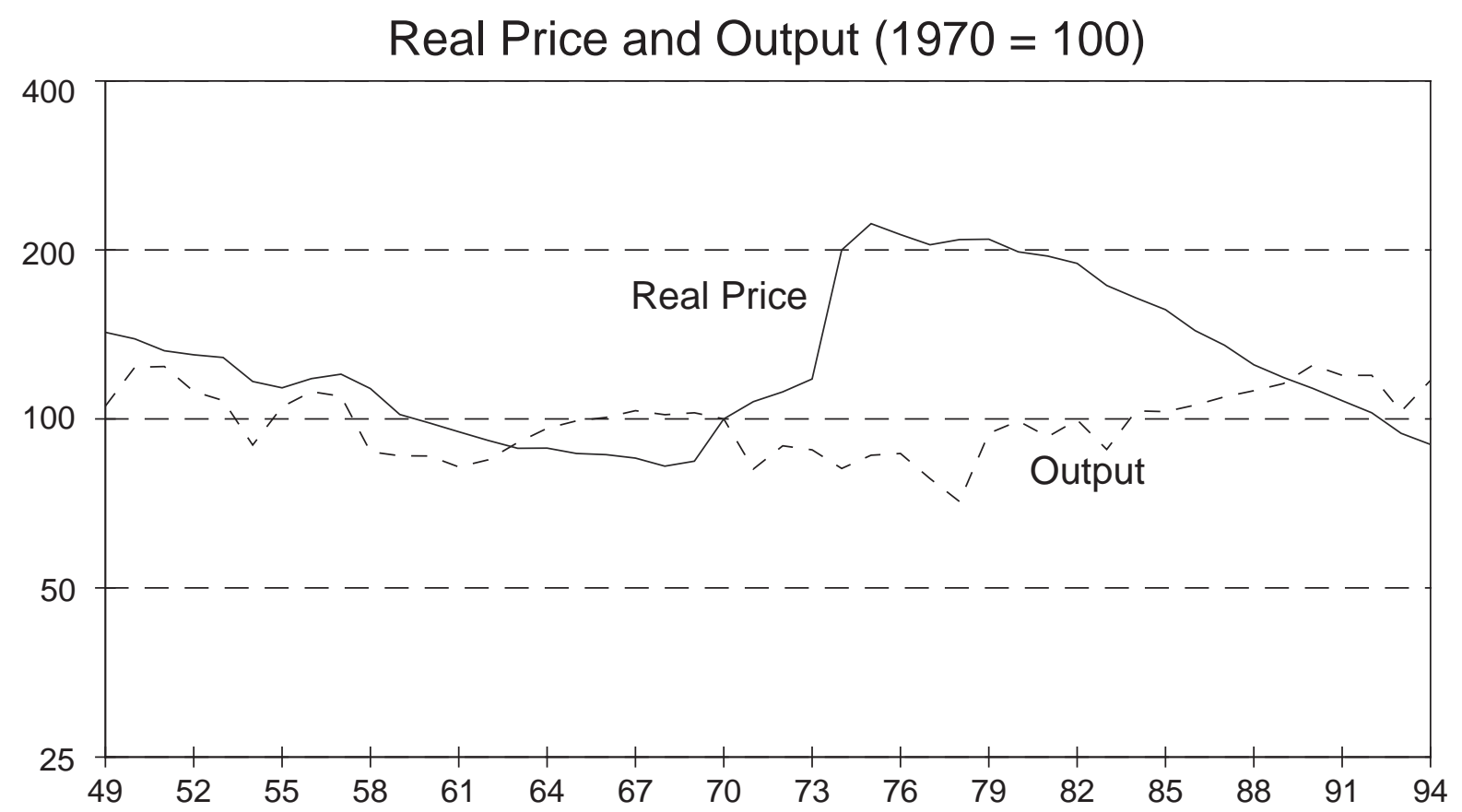


Figure 2c

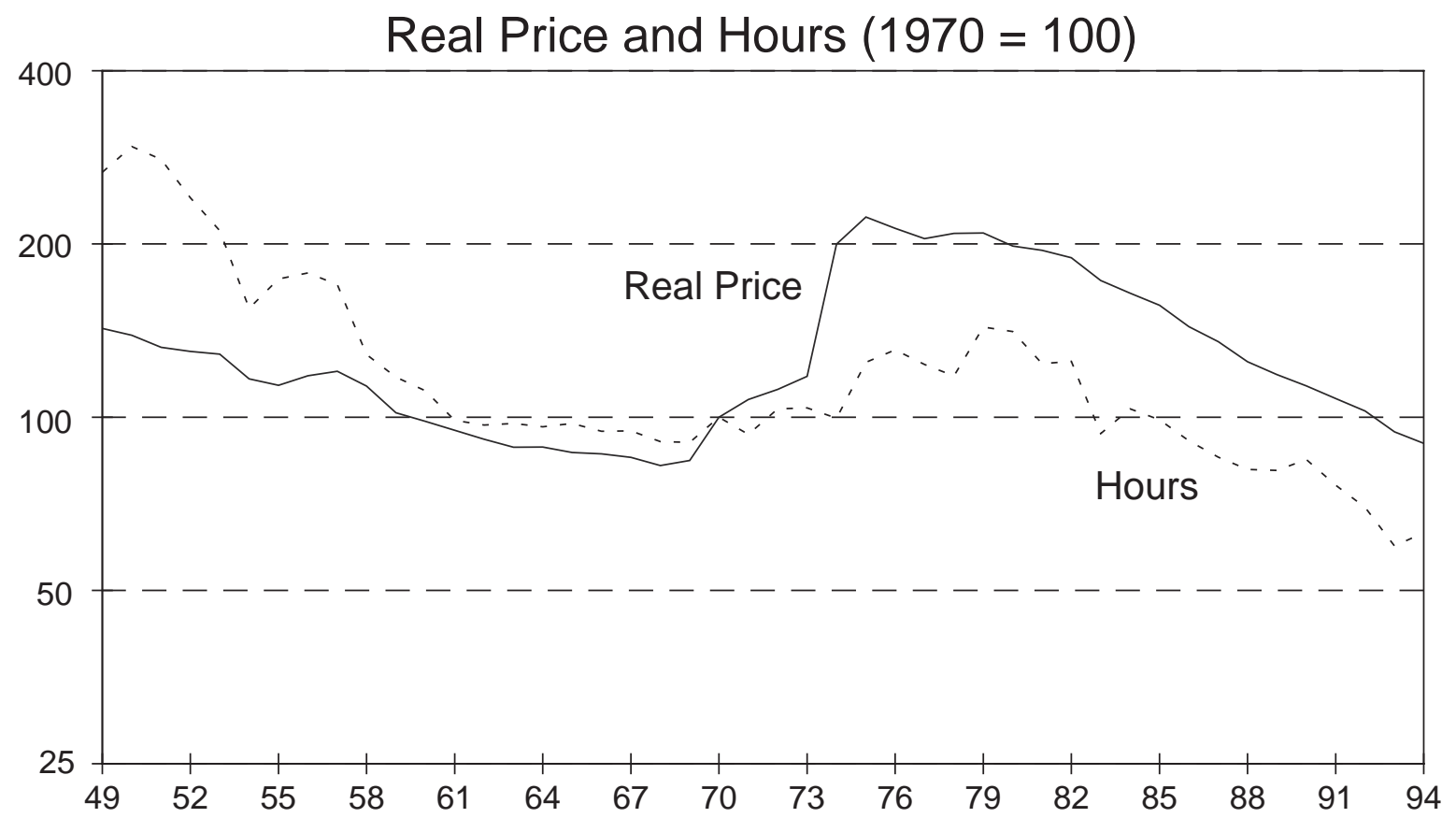

Source: Energy Information Administration, U.S. Department of Energy (1996). The chain linked GDP deflator is used to deflate coal prices for the 1959-94 period. For years prior to 1959, I use the implicit price delator (source: Economic Report of the President 1978, p.262) after multiplying by factor 0.99 . This procedure gives the same real price for 1959 as does deflating by the 1992 dollar chain linked deflator. 